\title{
Students' Preparedness towards the Study of Graphic Design: The Case of UEW
}

\author{
Esseku, J. F.* \\ Department of Graphic Design School of Creative Arts University of Education, Winneba - Ghana \\ *Corresponding Author: Esseku, J. F., Department of Graphic Design School of Creative Arts \\ University of Education. Winneba - Ghana
}

\begin{abstract}
This paper grounded in the mixed-method design and descriptive analysis, is aimed at investigating the impact of seventeen students' preparedness towards the study of Graphic Design at the University of Education, Winneba. These students do not have the basic tool; personal laptop to execute assignments and project works. The purpose of this study therefore was to determine the effect of students' unprepared attitudes regarding the inability to acquire personal laptops on their study of Graphic Design programme at the University of Education, Winneba. The researcher looked at two level groups within the Department of Graphic Design of the University of Education, Winneba and how this attitude affect teaching and learning of the three course paths students' study. The two level groups investigated offered three study paths at the Department of Graphic Design viz; Advertising, Graphic Design and Multimedia. These senior members and students were purposively selected to obtain data for this paper using the unstructured interview and observational methods. Primary data obtained were analysed descriptively and narratively. The inability of Graphic Design students of the Department of Graphic Design to acquire personal laptops affected teaching and learning. The effects of this attitude trickled down to the course instructors. It turned out that these number of students that do not possess personal laptops to assist in their studies increased with each year group. The researcher further interacted with two senior members within the Department of Graphic Design through the purposive sampling technique to secure data for this paper. The researcher recommends that the Department of Graphic Design through the University of Education, Winneba in partnership with a private company sell high end laptops on credit with a payment plan to be spread over the duration of their studies through a signed contract in solving this challenge.
\end{abstract}

Keywords: Advertising, graphic design, laptop, multimedia, project, Winneba

\section{INTRODUCTION}

Learning graphic design does not only involve creativity, it is dependent on the right tools and materials the artist possesses and the lack of the right tools and materials affect the outcomes. When inability of the student to acquire the tools and materials for his/her study affects the attitudes of learners form towards learning (Anthony \& Walshaw, 2007; Grootenboer et al., 2008; Kele\& Sharma, 2014). According to Han \& Carpenter (2014) and Mensah et al (2013) attitudes tie with cognitive, effective and behavioural reactions that one would display towards a situation based on their feelings or interest. Maio \& Haddock (2009) as well as Sanchal \& Sharma (2007) ascribed that the cognitive component is what the individual thinks. Thus, effective component is that which drives students' attitude towards his/her studies or interest.

The Department of Graphic Design at the University of Education, Winneba (UEW) in Ghana offers a bachelor-level design education in the field of advertising, graphic design and multimedia (interactive digital). The Department of Graphic Design put user needs first and implement its teaching to solutions to real world problems. The Department of Graphic Design at University of Education, Winneba provides students the opportunity to improve their skills as designers. As designing is an interactive process, it ties itself with current state of art equipment in the field of design and appropriate technology that facilitates the processes of design and production (DGD: UEW, 2018). For national governments to diversify their economies, there is the need to train human capital that would help carry out and support this transformation the world over today (AAU, 2015).

It is in this direction the government of Ghana today has implemented the free Senior High School policy during the 7th parliament of the 4th republic popularly known among Ghanaians as "Free 
SHS" that has come to stay to enable the youth and families that could not afford to educate their wards to the senior high school level have hope (Tamanja \& Pajibo, 2019; Nurudeen et al., 2018). Public universities are expecting large student intakes during the 2020/2021 academic year due to the "Free SHS". According to Von Glasersfeld, (1995) and Singh \& Rana, (2004) every nation could be seen through the mirror of her educational reforms as reflected in her population. The government of Ghana has changed the educational narrative of Ghana today, the government overwhelmingly spent huge amount on education as it was justified by the Deputy Finance Minister that there was the need to invest in the education of its children, who would lead the nation in the near future (GhanaWeb, 2019). The government of Ghana as well has continued to visibly enhanced TVET $^{1}$ through COVET $^{2}$ to produce a globally competitive workforce through quality-oriented and demand-driven learning for national development (The World Bank et al., 2014). The government has further introduced and emphasised the $\mathrm{CBT}^{3}$ in the recent TVET education all in the effort to produce technical manpower to advance the industrialisation of the nation as it exists in advanced nations (Ansah \& Kissi, 2013). According to Joy Online (2020), the government of Ghana of the 7th parliament of the 4th republic has also built two first-ever creative arts schools to horn the need to vary the focus of education in Ghana today. The COVID-19 pandemic exposed nations that were behind in information and technology as it forced the world to stay and work from homes.

In the work of Stanojević et al. (2018), since teaching aids is changing to suit the constant educational process, computers are becoming more necessary as an active acquisition of knowledge and creativity. Since the introduction of computers into education in 1970, computers have since been necessary in education today (Fouts, 2000). The Department of Graphic Design like other departments of public universities in Africa is underfunded and under sourced; and likely to affect quality of tertiary education (Twene, 2014; Goode, 2017; Daniel, 2012). The Department of Graphic Design shares a multimedia studio with the Department of Art Education also at the University of Education, Winneba which obviously put pressure on the usage of the multimedia studio by students. Due to the large volume of students who use the multimedia studio on weekly bases, students do not have the luxury to stay behind to complete their project and assignments during lectures in the week but to complete their assignments and projects out of class. The researcher studied seventeen students that made up of six level three hundred students and eleven level two hundred students during the 2019/2020 academic year. Primary data were also sought from two senior members of the Department of Graphic Design.

The Department of Graphic Design offer three flagship programme pathways under the Bachelor of Arts in Graphic Design viz; advertising, graphic design and multimedia through theory and practice. The three programme pathways run series of computer-generated graphic design courses under each pathway a student opt for. Current graphic design demand appropriate technology and facilities for its processes and production. The personal computer for that matter the laptop due to its convenience becomes the basic tool in the collection of every design students' tool is inevitable. Just like the lack of scribbling tools cannot be inevitable in any school going pupil, the lack of the laptop in the life of a graphic design student is a challenge for the instructor and the student and this affects teaching and learning. Students at the Department of Graphic Design are luckily to pick up to five design assignments in a week from their course instructors and during such times the importance of having a laptop is felt. Instructors insist on deadlines for the submission of projects and students without laptops felt the pressure. The attitude of graphic design students without laptops is growing without any plan in place to secure one before these categories of students finish their study and this attitude affects students' learning outcomes and teaching (Sanchal \& Sharma, 2017; V. N. Q. Teye, personal communication, September 15, 2020).

Looking at the growth trend of students without laptops at the Department of Graphic Design, and the high number of students the department is expecting due to the "Free SHS" policy operating in Ghana today, the unpreparedness of Graphic Design students to possess personal laptops would be a major challenge to affect teaching and learning for a longer time. Computers, and for that matter laptops, have become standard equipment in higher education today (Weaver \& Wilson, 2005). The ability of a university student to possess a laptop in inevitable in education today. Research suggests that there

\footnotetext{
${ }^{1}$ Technical and Vocational Education and Training

${ }^{2}$ Council for Technical and Vocational Education and Training

${ }^{3}$ Competent Based Test
} 
are three different components of attitude. These are the cognitive component, the affective component, and the behavioural component (Eagly \& Chaiken, 1993). The behavioural component occurs in the responds to the attitude object; and students without laptops prefers to skip lectures than to sit in without learning along. Jones \&Eiser (2014)have shown that formation of attitude is experimental. Mensah, et al. (2013) opined that people form attitudes through their experiences in life. Students in level three hundred have been on their programme without laptops so level two hundred students without laptops have braced themselves to also manage the situation till they graduate. Students without personal laptops depends solely on the multimedia studio of the Department of Graphic Design and some course mates who allowed them to use their laptops to complete their projects and assignments. This attitude comes with its varied consequences; late at handing in projects and assignments as students without laptops perpetually hand in projects late in the sight of the instructors. This common challenge affects teaching when these students are forced to stay up late nights at course mate hostels while using their laptops only end up sleeping during lectures. OECD (2015), gathers students that have and use computers more differ in several observable and nonobservable ways from those that have more limited access to computers, or use them less. Specialists in the field of education have shown more interest in issues that affects the learning process (Anghelache, 2013).

Some Graphic Design students do not bother themselves in possessing personal laptops for the mere reason that their parents or guardians are not able to afford a laptop in addition to their facility user fees and other expenses. It is rampant amongst students to skip lectures since they would not be able to follow in their lectures when they have missed quizzes and their assignments rejected because they could not meet submission deadlines. This attitude affected their performance when practical examination projects were also rejected based on their inability to meet submission deadlines. Lecturers do not attend to this category of students during practical sessions as they sit idly because they are unable to follow practical lesson. Lecturers found it challenging when students who were not in class the previous week because they could not borrow a laptop to complete assignments and make it to the following class and he/she drags the class back when new computer program tool is introduced and its usage is demonstrated.

This attitude by students often kept the lecturers on their toes to meet discussion of results deadlines at the department and faculty levels. This attitude by students again posed as a challenge to lecturers when lecturers have to find the where about of students when their practical projects does not come in during assessment to ascertain why the lecturer does not have their projects. The situation causes inconvenience and sometimes an embarrassing situation for the lecturers not to talk of the poor performance such students achieve which the lecturers are required to answer during departmental academic committee meeting to discuss results.

\section{Methodology}

This paper adopted the mixed method which offered the researcher a legitimate use of multiple approaches in providing answers to the demands of the paper. The qualitative and quantitative approaches and the descriptive analysis concurrently merge with the purposive sampling technique formed one interpretation of the basis of the data that influenced selecting nineteen subjects from the Department of Graphic Design as samples for the study. The samples were made up of eleven males representing $63.16 \%$ while eight were female subjects represented $36.84 \%$ of the nineteen total sampled. Six students representing $31.58 \%$ of the total sampled were from level three hundred. Out of the six sampled from level three hundred, four subjects represented $66.67 \%$ were males and two females representing $33.33 \%$; eleven subjects sampled represented $57.89 \%$ were from level two hundred; this number consisted of seven male students represented $63.64 \%$ and four female students represented $36.36 \%$; and two senior members represented $10.53 \%$ consisted of equal gender.

The purposive sampling technique was favoured because initial studies towards this study indicated varied but similar reason why these students do not have laptops and how this attitude has cost them. The two senior members came up with same challenges they faced that affects their work. Two issues came up during the interaction with the subjects; in sum the students' attitude of not possessing laptops for their studies affects teaching and learning. Levels hundred and four hundred students were excluded from the study because the final year students would be out of campus to undertake internship for a semester as part of their studies while for convenience the researcher excluded level hundred students who had varied excuses that included; their guardians were sending in their laptops 
soon and took most of the foundation courses that did not require vigorous use of the personal computer.

The researcher interacted with the senior members if they have made efforts to encourage these categories of students to possess laptops, the students' attitude affected teaching in and out of class, when they hand in assignments; and generally, and how this category of students' attitudes affected their performance. One of the senior members taught Graphic Design courses and Multimedia courses while the other senior member taught only multimedia courses. These two senior members taught more than two courses to these categories of students in each week. One of the senior members had over ten years teaching experience in graphic design and multimedia courses while the other senior member had three years teaching experience in multimedia courses. These two senior members were purposively selected to obtain data for this paper using the unstructured interview and observational methods while they helped in selecting the students for the primary data.

\section{RESUlTS AND DisCUSSIONS}

Students were shocked to realise that the study of Graphic Design was financially demanding at the university level compared to the Visual Art subjects they studied at the senior high school level. Students did not know they required laptops for their programme since they virtually did not financially invest in graphic design tools and materials at their Senior High School studies. The interrogations with the students sampled indicated that eleven representing $64.71 \%$ lived with single parents. This category of students found it difficult to fully settle their school fees at the beginning of each academic year. Six of the total sampled representing $35.29 \%$ lived with both parents. This category of students had other siblings in other tertiary institution and their parents' finances is low to support them in acquiring laptop for their studies. Out of the total students sampled, eight representing $47.06 \%$ were either supported by a guardian, sibling or external relations. Two of the total sampled students representing $11.76 \%$ being males fully supported their education fully and had to even support the home financially. Considering the situations of these students sampled, they could not burden their single parents, guardians or older siblings to get them a personal laptop.

It was evident in the investigations with the students that due to the financial demands of the Graphic Design programme, twelve representing $70.59 \%$ of the total students sampled wished they could change their programme to Art Education which did not necessarily demand a personal laptop due to the nature of the courses at the Department of Art Education compared to courses at the Department of Graphic Design. Out of the twelve students sampled, three which represented 25\% were females and the remaining nine of these categories of students represented $75 \%$ were males. It also emerged that finance was the major issue that hampered their inability to acquire a personal laptop. The students neither had an alternative option to acquire a laptop and the students depended on their course mates to lend them their laptops for use. Students who borrowed laptops to execute their assignments and project works had to wait until the owner completed his/her work on the laptop.

It also emerged that students did not have the opportunity to take away the borrowed laptops from their mates to their hostels but forced to use the laptop under the observations of the owner at his or her hostel. This situation left the students to arrive at their hostels very tired, late and without food. It came up that some course mates lack of time to complete their assignments and project works on time to meet deadlines are forced to disappoint their colleagues who had arranged to borrow their laptops. Five students sampled representing $29.41 \%$ shared how they were punished when they could not submit either assignments or project works as scheduled and this situation affected the final grades for the semester. Eight students sampled represented $47.06 \%$ skipped lectures when they were unable to submit assignments or projects on scheduled as they are often noted for such an attitude and they felt embarrassed. Three students of the sampled representing $17.65 \%$ did not submit end of semester examination projects because they did not get a borrowed laptop during the heat of end of semester examination but took supplementary examinations to complete their academic work for the semesters. This attitude contributed to the students' underperformance in their examinations. Thirteen students sampled representing $76.47 \%$ indicated that lecturers have called them during holidays demanding their end of semester examination projects; giving them an ultimatum date to submit their examination piece or they face the possibility to fail in the examination.

Ten students from the total seventeen students sampled representing 58.82\% where professional teachers who said they read the wrong programme, instead they would have read Art Education 
programme which had Education component while they studied Graphic Design. Their decision was influenced by the fact that they could not afford to go to the industries for internship but instead went for teaching practice which they were familiar with such practice. These students were on study leave and would obviously go back to the classroom to teach and not set up their own businesses after school. These students did not know that there was difference in the Graphic Design Programme and the Graphic Design specialization under Art Education Programme until they arrived on campus and started lectures. Out of their disappointment, they did not have the urge to obtain a loan to procure a laptop for their studies. They felt they would gain employment into teaching if they had studied Art Education programme than they have to study post-graduate programme in Education to qualify them to get into the teaching profession. With this disappointment, four students representing $23.53 \%$ agreed their attitude had direct negative effect on their performance every semester. These students wished they could change their programme but could not stand the shame when their colleagues should realise they switched programme because of their underperformance.

Interacting with the two senior members of the Department of Graphic Design sampled, emerged that students without personal laptops negatively affected teaching. Students skipped lectures and when the students are forced to attend lectures the result is that it drags the lecture for that day back since they had missed previous lessons. These students asked questions which were dealt with in previous lesson session which the student skipped. It was difficult for the lecturers to complete their lesson on scheduled for which students who had skipped previous lectures attend. "Students who did not have their own laptop could not answer question(s) put before them or could not demonstrate an action in class for clarification during a practical lesson" (Senior member B posted). Students in this category suffered in examinations and scored low grades. Students without laptops did not have the opportunity to practice over and over of the lessons they take for perfection of skills taught. It was confirmed students skipped lectures when students' work is critiqued in class or brought in their project works for supervision.

It was evident again from the interactions with the senior members that "students without personal laptops did not turn in their assignments and projects on time and often disrupt their schedule and release of examination results" (Senior member B observed). It was confirmed that senior members had to call students on their cell phones because they did not submit examination practical pieces before leaving for home on school holidays. When students are not able to meet the opportunity to submit examination project piece after the scheduled date, the students failed their examination. It was evident that students do not prepare enough with the requisite tools and materials for their studies as students gave financial reasons for their inability to print and submit projects in some instances a senior member lamented.

It again emerged that "students without personal laptops did not make the effort to obtain one and that forced such students to be truant in class" (Senior member A lamented). This attitude by students forced lecturers not to have a pleasant relationship with these students. Lecturers often found themselves in an embarrassing situation to remark on why a student had a missing grade during departmental board meeting especially when the lecturer had made efforts to reach the said student without success. The number of students on the three course paths in each year group are rising and overwhelms the lecturer to make enough time for each student coupled with their extra curriculum activities bestowed on the senior member. Students refused to meet with their academic counsellors to share their academic challenges for support. Some students confided in one of the senior members they sometimes skipped lectures to take up part-time jobs to support their upkeep. "The divided attention was a serious setback to learning" the senior member observed. There has been substantial evidence that using technology as an instructional tool enhances students learning and educational outcomes (Gulek\&Demirtas, 2005).

\section{CONCLUSION AND RECOMMENDATIONS}

International schools offering Graphic Design programmes do list the laptop as a requirement to study their programmes. Students without laptop today would not be able to follow lessons in Graphic Design studies. The Graphic Design, Advertising and Multimedia pathway at the Department of Graphic Design run twenty-seven Computer Aided Design (CAD) courses within four semesters of the second and third years, for this study out of the total of forty-seven courses taken. This translates into $78.72 \%$ of CAD courses taken within two years of a graphic design study time at the Department of Graphic Design. Without laptop and its related challenges that had been identified, go a long way 
to affect teaching and learning of Graphic Design. The Department of Graphic Design courses are mostly tailored for the use of laptops and have an entirely different experience when a student sits in without a laptop. In many classes and labs, computers are necessary and learning depend on immediate and constant access to computers during class time.

The inability of students to procure laptop for their studies has a negative effect on their studies as well as affecting lecturers' job including assessment. As pupils are not able to be in school without scribbling tools and materials, the graphic designer could not study Graphic Design effectively without the basic tool(laptop) today. It is becoming attitudinal today that a Graphic Design student goes through a four-year study without laptop and not make any effort to obtain one. Observing the progressive increase in admission trend into universities lately in Ghana, if this attitude by graphic design students enrolling on Graphic Design programmes without a laptop is not checked good and professional graphic designers would not obviously be produced to fill the job market. Graphic Design students without laptop are unable to take up freelance to support themselves when they are on holidays and when they are done with their study and while they scout for jobs. With the expansion of technology today, the demand for great designers will increase opening a massive growth potential. The benefits of possessing a laptop outweighs its cost today in tertiary education.

The findings and limitations of the present study suggest several avenues for future research, which can be summed up as "why". Why would graphic design students study Graphic Design programme without a laptop. Once researchers and educators better understand the importance of the laptop in learning graphic design today, more strategic sensitization can be developed and inculcated in the visual art students in the senior high school level before they make their way to study at the tertiary level. Second, future research should begin to examine the favourable approach to enable students from less privileged homes procure laptops for their studies from a third party through the University of Education and the cost spread over the duration of the students' study period to be paid. The Department of Graphic Design could include as part of its admission qualification requirement a laptop and design application subscriptions to its potential applicants.

Future research may also be improved by finding ways to monitor laptop use directly amongst graphic design students. This would avoid the challenges students without laptops go through out of class. This type of data would undoubtedly give a clearer picture why a graphic design student could not study Graphic Design programme without a laptop. Students need to develop positive attitude towards the programme as an important factor in the formation of students' attitude towards the subject. Future research too could compare the outcomes of students with laptops versus those without laptops.

Ultimately, however, these results clearly demonstrate that the use of laptop in the study of Graphic Design is invaluable and without the laptop, it has serious negative consequences. These results suggest that the negative influence is two-pronged; affecting learning as the student is not able to participate fully in the lessons while the student skip lectures. The other face of the results is the effect of the students' attitude on teaching on the part of the lecturer. Though several other researchers have otherwise suggested that laptops should not be used in classes where they are not integrated into the course (Barak et al., 2006; Gay, Stefan one, Grace-Martin, \& Hembrooke, 2001) as cited by Fried, 2006. I believe the story would hold today.

\section{REFERENCES}

[1] AAU. (2015). Towards innovative models for funding higher education in Africa. Association of African Universities.

[2] Abdul-Rahaman, N., Abdul Rahaman, A. B., Ming, W., Ahmed, A.-R., \& Salma S., A.-R. (2018). The free senior high policy: An appropriate replacement to the progressive free senior high policy. International Journal of Education and Literacy Studies, 6(2), 26-33. https://doi.org/10.7575 /aiac.ijels.v.6n.2p.26.

[3] Anghelache, V. (2013). Determinant factors of students' attitudes toward learning. Procedia - Social and Behavioral Sciences, 93, 478-482. https://doi.org/10.1016/j.sbspro.2013.09.223.

[4] Ansah, S. K., \& Kissi, E. (2013). Technical and vocational education and training in Ghana: A tool for skill acquisition and industrial development. Journal of Education and Practice, Vol.4(16), 172-180. https://www.researchgate.net/publication/305475999_Technical_and_Vocational_Education_and_Trainin g_in_Ghana_A_Tool_for_Skill_Acquisition_and_Industrial_Development.

[5] Anthony, G., \& Walshaw, M. (2007). Effective pedagogy inmathematics/pangarau: Best evidencesynthesis iteration (BES). Ministry of Education. 
[6] Barak, M., Lipson, A., \& Lerman, S. (2006). Wireless Laptops as Means For Promoting Active Learning In Large Lecture Halls. Journal of Research on Technology in Education, 38(3), 245-263. https://doi.org/10.1080/15391523.2006.10782459.

[7] Daniel, J. (2012). The future of open education. Paper presented at UNESCO Bangkok Thailand, Special Summer Seminar 2012.

[8] Eagly, A. H. \& Chaiken, S. (1993). The psychology of attitudes. Harcourt Brace Jovanovich College Publishers.

[9] Fouts, J. T. (2000, February). Research on computers and education: Past, present and future. http://docshare01.docshare.tips/files/31705/317050658.pdf.

[10] Fried, C. B. (2008). In-class laptop use and its effects on student learning. Computers \&Education, 50(3), 906-914. https://doi.org/10.1016/j.compedu.2006.09.006.

[11] Gay, G., Stefanone, M., Grace-Martin, M., \& Hembrooke, H. (2001). The Effects of Wireless Computing in Collaborative Learning Environments. International Journal of Human-Computer Interaction, 13(2), 257-276. https://doi.org/10.1207/s15327590ijhc1302_10

[12] GhanaWeb. (2019, August 5). Government justifies expenditure on Free SHS. https://www.ghana web.com/GhanaHomePage/NewsArchive/Government-justifies-expenditure-on-Free-SHS-769389.

[13] Goode, F. (2017). Approaches to Ghana's higher education challenges drwan from the U.S. community college model. Walden university: Columbia, MD. Accessed at https://scholarworks.wald enu.edu/cgi/viewcontent.cgi?article $=5907 \&$ context=dissertations .

[14] Grootenboer, P., Lomas, G., \& Ingram, N. (2008). The affective domain and mathematics education.In H. Forgasz, A. Barkatsas, A. Bishop, B. Clarke, S. Keast, W. T. Seah, P. Sullivan (Eds.), Research in mathematics education in Australasia 2004-2007 (pp. 255-269). Sense.

[15] Gulek, J. C. \& Demirtas, H. (2005). Learning with technology: The impact of laptop use on student achievement. Journal of Technology, Learning, and Assessment, 3(2). Retrieved from https://ejournals.bc.edu/index.php/jtla/article/view/1655.

[16] Han, S. Y., \& Carpenter, D. (2014). Construct validation of student attitude toward science,technology, engineering and mathematics project-based learning: The case of Korean middlegrade students. Middle Grades Research Journal, 9(3), 27-41.

[17] Jones, C. R., \& Eiser, J. R. (2014). Attitude Formation Through Exploration. SAGE Open, 4(3), 215824401455192. https://doi.org/10.1177/2158244014551927.

[18] Joy Online. (2020, September 27). 9 new model schools to be completed by end of 2020 - Education Minister. Myjoyonline. https:/www.myjoyonline.com/news/national/9-new-model-schools-to-becompleted-by-end-of-2020-education-minister/.

[19] Kele, A., \& Sharma, S. (2014). Students' beliefs about learning mathematics: Some findings from theSolomon Islands. Teachers and Curriculum, 14, 33-44.

[20] Maio, G. \& Haddock, G. G. (2009). Psychology of attitudes and attitude change. Sage.

[21] Mensah, J. K., Okyere, M., \& Kuranchie, A. (2013). Student attitude towards mathematics and performance: Does the teacher attitude matter? Vol. Vol.4 (3rd ed.). Journal of Education and Practice.

[22] OECD (2015). "How computers are related to students' performance", in Students, Computers and Learning: Making the Connection, OECD Publishing.

[23] Sanchal, A., \& Sharma, S. (2017). Students' attitudes towards learning mathematics: Impact of teaching in a sporting context. Teachers and Curriculum, 17(1), 89-99. https://doi.org/10.15663/tandc.v17i1.151.

[24] Singh, R. P., \& Rana, G. (2004). Teaching Strategies. APH Publishing Corp.

[25] Stanojević, D., Cenić, D., \& Cenić, S. (2018). Application of computers in modernization of teaching science. International Journal of Cognitive Research in Science Engineering and Education, 6(2), 89-104. https://doi.org/10.5937/ijcrsee1802089s.

[26] Tamanja, E. \& Pajibo, E. (2019, July). Ghana's free senior high school policy: Evidence and insight from data. EDULEARN19 Proceedings, 7837-7846. https://doi.org/10.21125/edulearn.2019.1906.

[27] The World Bank, Ministry of Foreign Affairs of Denmark (DANIDA), \& COTVET. (2014, April). Ghana skills and technology development project (GSTDP) (No. P118112). Council for Technical and Vocational Education and Training (COTVET). http://sdfghana.org/cp/images/reports/Final\%20DRaft\%20GSTDP\% 20MRT\%20Report.pdf.

[28] Twene, P. (2014, April). Sources of funding for higher education in Ghana.Department of Education, Faculty of Education Science. Universitetet i Oslo.https://www.duo.uio.no/bitstream/handle/10852/ 41689/Twene-Pius-Thesis.pdf\%3Fsequence\%3D1.

[29] UEW. (2018, April 05). News. Retrieved from University of Education, Winneba: https://www.uew.edu. $\mathrm{gh} /$ news/acting-head-department-graphic-design-attends-fitc-design-conference-amsterdam

International Journal of Humanities Social Sciences and Education (IJHSSE)

Page $\mid 33$ 
[30] Von Glasersfield, E. (1995). Radical Construction. Palmer.

[31] Weaver, B. E., \& Nilson, L. B. (2005). Laptops in class: What are they good for? What can you do with them? New Directions for Teaching and Learning, 2005(101), 3-13. https://doi.org/10.1002/tl.181.

Citation: Esseku, J. F. "Students' Preparedness towards the Study of Graphic Design: The Case of UEW" International Journal of Humanities Social Sciences and Education (IJHSSE), vol 8, no. 2, 2021, pp. $27-34$. doi: https://doi.org/10.20431/2349-0381.0802004.

Copyright: (C) 2021 Authors. This is an open-access article distributed under the terms of the Creative Commons Attribution License, which permits unrestricted use, distribution, and reproduction in any medium, provided the original author and source are credited. 